\title{
Edutainment and HIV/AIDS in Botswana: A Content Analytical Discourse on 'Morwalela' Drama Series
}

\section{Choja Oduaran}

Associate Professor, Department of Psychology, North-West University, South Africa and Indigenous Language Media in Africa (ILMA) Entity, SOUTH AFRICA

sc 14065307700

\section{Okorie Nelson}

Senior Lecturer, Covenant University, Nigeria and Indigenous Language Media in Africa (ILMA) Entity, NIGERIA

(iD) 0000-0003-1207-1343 SC 56299640200

nelson.okorie@covenantuniversity.edu.ng

\begin{abstract}
ARTICLE INFO
Received: 29 May 2018

Accepted: 25 October 2018

Published: 21 December 2018

DOI: https://doi.org/10.29333/ojcmt/3987

ABSTRACT

The Joint United Program on HIV/AIDS (UNAIDS Data 2017) facts states that 360, 000 people out of a population of over two million people in Botswana are affected with HIV/AIDS (including women and children), with 3,900 deaths related to AIDS alone. Despite the fact that antiretroviral medications are being distributed freely to all the people living with HIV/AIDS in Botswana, the country is still one of the countries greatly affected by HIV/AIDS in the world. This study, therefore examined the role of the drama series 'Morwalela' (as a complimentary development strategy), in addition to the HIV/AIDS prevention, testing and treatment strategies and campaign in Botswana. The theories underpinning this study were development media theory and framing theory. The method adopted for data gathering was content analysis, which was a qualitative method of research. Purposive sampling method (which is a non-probability sampling technique) was used for the selection of the drama series for this study. This study was conducted by examining various themes (both positive and negative), the direction of media frames, as well as other factors such as the recurring comments, and the frequency of viewership. Finding showed that over 75, 000 people worldwide had viewed the 'Morwalela' drama series on YouTube. Also, the theme of 'Love' had the highest percentage which was $13 \%$, from 84 scenes, followed by the positive theme of 'Family' with $10.7 \%$. Tolerance was the lowest with $1.2 \%$. Infidelity was the highest negative theme with $11.9 \%$. Furthermore, the result showed that $26.7 \%$ of the frames in the movies, out of 30 frames focused on HIV/AIDS discussions and coping mechanisms of HIV/AIDS victims. It was recommended that the government of other South African countries-like Lesotho, Swaziland and Namibia should focus more on partnerships with both governmental and non-governmental organisations for curbing the danger of HIV/AIDS.
\end{abstract}

Keywords: analytical discourse, Botswana, edutainment, HIV/AIDS, Morwalela drama series

\section{INTRODUCTION}

In Southern Africa, edutainment programmes have been used to combat health issues, highlighting prevention tactics and coping mechanisms. For example, 'Intersexions', was an edutainment television drama that created awareness and knowledge about health 
issues. This drama series was South Africa's most watched television series and the second most watched television show overall on the South African Broadcasting Corporation (SABC). Total viewership for the show exceeds 4 million viewers across South Africa. It was produced by Curious Pictures and Ants Multimedia, in partnership with John Hopkins Health and Education in South Africa (JHHESA) and SABC Education (John Hopkins Center for Communication Programs, 2010).

The success of Intersexions drama series led to the advent of more edutainment programmes for sustainable health development in Southern African countries. In Botswana, the drama series 'Morwalela' was aired between April and June 2010 on Botswana Television (BTV). Morwalela is one of Botswana's edutainment series, which was back by popular demand, because of the overwhelming feedback by its audience. The story was developed by local writers Wame Molefhe and Lauri Kubuitsile, the screenplay was written by Peter Goldsmid and was produced by Traffic Productions (Gwakuba, 2010). The film series 'Morwalela' was produced as a result of a strong partnership between the United States, Civil Society Partner and the government of Botswana. The film series was produced and aired with the motive of combating the epidemic of HIV/AIDS, which is prevalent among a certain percentage of youths in Botswana, using the tactic device of the mass media to bring up precautionary edges. The series is believed to be the first of his kind to be fully developed and produced within Botswana (Dzimiri, 2010). This series falls under the 'drama' genre.

As stated by the Narrator in the first few seconds of the second episode of the drama series, supported by Setswana Oxford Living Dictionaries (2018), Morwalela means 'rain', but in the context of the drama series, it means 'a flood of problems'. Morwalela, as stated in the opening episode is the name of a fictional community in Botswana. Morwalela has a variety of people-rich, poor, healthy, unhealthy, single, married etc., just like every other settlement. The story portrays each character, making decisions and choosing lifestyles that affects their family and friends either positively or negatively. Morwalela helps in emphasizing and addressing the negative part of the culture, by bring its consequences to light. The series focuses on how perilous manners are rooted, in association with befriending/dating the wrong people with the wrong dating ideologies and alcohol misuse. This series is however different. Instead of re-educating people about HIV/AIDS. It reemphasizes social adjustments and habit development and reformation of social norms that facilitate the spread of HIV/AIDS in Botswana (Dzimiri, 2010).

Interestingly, this edutainment drama series majorly aim at promoting positive lifestyle changes, showing prevention and treatment procedure, as well as showing coping mechanisms and rejecting the negative lifestyles and cultural values that aid in transmitting these diseases. Therefore, the aim of this study is to analyse the media frames (cultural issues, lifestyle, prevention, coping and treatment procedures) that address the issue of HIV/AIDS in the television drama series titled 'Morwalela'.

\section{PROBLEM STATEMENT}

According to Avert (2017), the Joint United Program on HIV/AIDS (UNAIDS Data 2017) facts states that 360,000 people out of a population of over two million people (Worldometers, 2018) are affected with HIV/AIDS (including women and children), with 3,900 deaths related to AIDS alone. Despite the fact that antiretroviral medications are being distributed freely to all the people living with HIV/AIDS in Botswana, the country is still one of the countries greatly affected by HIV/AIDS in the world. It has been established by Avert (2017), that there is low knowledge of the virus, as well as low testing 
rate by the people of Botswana. This study therefore, examines the role of the drama series 'Morwalela' (as a complimentary development strategy), in adding to the HIV/AIDS prevention, testing and treatment strategies and campaign in Botswana.

\section{RESEARCH QUESTIONS}

1. What are the prevalent themes in the edutainment drama series 'Morwalela' on HIV/AIDS?

2. What is the frequency of the viewership of the television drama series 'Morwalela' on its YouTube channel?

3. What is the direction of media frames in the television drama series 'Morwalela' on HIV/AIDS?

\section{SCOPE OF THE STUDY}

This study aims at thoroughly analysing the content of 'Morwalela', through content analysis. Morwalela is a Botswana drama. The researcher had access to the television drama series through YouTube. Thus, references and suggestions were made based on the contents of the television drama series 'Morwalela'. It has 8 episodes, but was uploaded as 9 parts on YouTube.

\section{THEORETICAL REVIEW}

This study was anchored on the development media and framing theories to understand how edutainment programmes can be used to promote heath care practices for HIV/AIDS.

\section{Development Media Theory}

This theory is one of the extensions of the four theories of the press. It was propounded by McQuial in 1987. It explains the behaviour of the media in developing countries, where there is complete or partial lack of communication structure, untrained staff without specialized skills, mostly illiterate audiences, non-existence of cultural production resources and lack of independence from the Western world. From the name 'development media', it can be deduced that the main target of this theory is to safeguard total development in the society. It opposes total authoritarian theory, which is the first theory of the press, and it seeks for development and nation building. It states that the media should be seen as partner to the government in ensuring good governance, development and social change (Asemah, 2011).

Part of the way that the media partners up with the government is to tackle an epidemic such as HIV/AIDS. This is what has been put to practice in Botswana with the programme 'Morwalela'. This was a television drama series created to disseminate the message of responsible sexual behaviour and tolerance of people living with HIV/AIDS in Botswana. The series set up an on-going communal conversation about the common sexual culture in Botswana. The film series 'Morwalela' was produced as a result of a strong partnership between the United States, Civil Society Partner and the government of Botswana. The film series was produced and aired with the motive of combating the epidemic of HIV/AIDS, which is prevalent among a certain percentage of youths in Botswana, using the tactic device of the mass media to bring up precautionary edges. The series is believed to be the first of his kind to be fully developed and produced within Botswana (Dzimiri, 2010). This is a team up by the United States government and the media to combat the issue of HIV/AIDS in Botswana. 


\section{Framing Theory}

Framing theory was propounded by Erving Goffman in 1974. It is an extension of the agenda setting theory. However, the ides of this study goes beyond agenda-setting. As explained is an article titled 'Framing Theory' (2014), "the basis of framing theory is that the media focuses attention on certain events and then places them within a field of meaning. Framing is important topic since it can have a big influence and therefore the concept of framing expanded to organisations as well...Framing is the way a communication source defines and constructs any piece of communicated information. In essence, framing theory suggests that how something is presented to the audience (called 'the frame') influences the choices people make about how to process that information".

Chong and Druckman (2007), stated that Communication scholars and political scientists generally use the term 'frame' in two ways: first, a frame in communication or a media frame refers to the words, images, phrases, and presentation styles that a speaker (e.g. a politician, a media outlet) uses when relaying information about an issue or event to an audience. Secondly, a frame in thought or an individual frame refers to an individual's cognitive understanding of a given situation (Goffman, 1974). Unlike frames in communication, which reflects a speaker's emphasis, frames in thought refer to what an audience member believes to be the most salient aspect of an issue (p. 101).

Therefore, if framing is often adopted for information dissemination, general communication and to lay emphasis on certain events and organisation, it can be applied to the dissemination about the HIV/AIDS epidemic in Botswana, through edutainment and other means. Framing was used in the drama series 'Morwalela', to educate about the prevention and the health maintenance strategies. This edutainment drama series is expected to have a subtle but powerful effect on the lifestyle of its audiences, in Botswana in the long run.

\section{EMPIRICAL REVIEW}

Cinema is in close touch with ideology as such in correlating with many conditions in society. As is known, the relation between ideology and cinema has become subject of several studies (Akter \& Dalkılıç, 2018, p. 165). Stories are effective communication tools because there are no one who doesn't like them. When a story is heard or listened, it can be a powerful communication tool to awake people's emotions. Therefore organizations should use storytelling as an effective communication tool...raising their awareness on certain issues. (Tören \& Özad, 2017, p. 79, Tuğçe, 2018, p. 131).

Aitken and Dey's (1998) study of film portrayal of people with HIV/AIDS focused mainly on highlighting the fact that there are two major categories of films about HIV/AIDS (i) films produced by the mass media e.g. television, movies, news, soap operas and (ii) films produced outside the commercial sphere-independent or 'activist' videos and films. The authors examined the movies 'Philadelphia', 'Longtime Companion', 'It's My Party', 'And the Band Played On', 'Jeffrey'. It was stated that all these movies fall into the first category- produced by the mass media. These movies are all about the subject matter of HIV/AIDS and some are about homosexuality. The authors concluded that, the movies produced by the mass media focus narrowly on the portrayal of sexuality. They focus on the negative sides- they tend to have similar features e.g. dying. They also focus positively on the portrayal of family and community. The films are paradoxical in nature, just as the entire AIDS epidemic has been.

Archiopoli (2009), studied and analyzed the film 'Rent' which was about HIV/AIDS and how eight characters who have been tested positive are struggling with their lives in New 
York. The film is an adaptation of a book. The methodology used for analysis was narrative criticism, which is a qualitative technique. The film was viewed multiple times over a one month period. The study of each character of the movie led to the creation of the HIV/AIDS Lifestyle Integration Continuum. The theme of HIV is prevalent throughout the film. Individual lifestyles of the different characters who are at different stages of HIV are shown.

Osaigbovo's (2012) thesis focused on film as a supplementary aid in teaching adults about HIV/AIDS in Igueben, Edo State, Nigeria. He stated that film as a campaign strategy impacts in a way that no other teaching aid can. The literature reviewed that reading materials about HIV/AIDS are not accessible to the people in rural community. Film is an accessible source. The study adopted mixed methodology (both quantitative and qualitative approach), using an interpretivist framework, with 200 members (purposively selected) of the rural community as participants. The results revealed that, films, especially Nollywood films, play a key role in informing people about HIV/AIDS and its treatment. The study recommended that film should be included in governmental and non-governmental initiatives, for more impact in the fight against HIV/AIDS.

Mafoko (2013) embarked on a mini-thesis in the University of Western Cape, South Africa, titled 'Process Evaluation of the Multiple Concurrent Partnerships 'O Icheke, Break the Chain' Campaign for HIV Prevention in Botswana from 2009-2012'. The study focused on conducting an evaluation of the campaign, taking account of it simple implementation plan. The author wanted to find out if the programme components originally structured, were implemented and whether any issues that had risen required attention. A descriptive study design was used. The results indicate that everything went according to plan, except the recruitment of campaign champions because of lack of adequate funds. Also, the support for the district level implementation of campaign activities such as capacity building and advocacy were also affected by delayed funding. This study was based on the behavioural theory and evidenced on health communication programming.

Matlapeng (2014) also focused his work on the 'O Icheke' campaign, which was created to address the problem lack of information about HIV, and to curb transactional sex and intergenerational sex. It was also created to give information about the culture, sex and relationships. It was a campaign coordinated by National AIDS Coordinating Agency, with the African Comprehensive HIV/AIDS Partnership (ACHAP), as a major funding partner among other partners. Matlapeng (2014), in his study of 'Perceptions About The O Icheke Multiple Concurrent Partnerships Campaign Among Young People Who Are Member Of The Selebi Phikwe District Youth Council In Botswana', stated that the main target of this study was (i) to reconnoitre the perspectives of youths about multiple concurrent partnerships (ii) to explore young people's perspectives on the main strong points and flaws of the $\mathrm{O}$ Icheke campaign (iii) to make recommendations to further make the campaign stronger. The author supported his work with the health belief model, using focus group discussion, which is a qualitative approach to gather data for the study. The data was categorised into males and females between the ages of 18-24 years and 25-35 years. The key result was that there are factors fundamental to the practise of multiple concurrent partnerships in Botswana which include 'financial issues, need for sexual variety, materialism, unemployment, migration and alcohol abuse. The results also show that the campaign also looked into the aspect of provision information and the impact of partnerships in behavioural change. The study therefore recommended that there should 
be enhancement in the enactment of the O Icheke programme by fund/aids, discussion and aptitude development.

Moore, Onsomu, and Abuya's (2014) study on 'HIV prevention using films: HIV/AIDS positive African American women respond through interpersonal relationships in life support', focuses on the effect of HIV/AIDS on the African American community. It was stated that there are more than 25 percent of African women, among others in the black community who had tested positive in 2010. Due to this shocking statistics, social campaigns which includes movie, were created for behavioural change among Black American women living with HIV/AIDS. 'Black feminist thought' was used as the conceptual framework for this study. This was used to comprehend the life style of 'Ana' who was the protagonist of the film analysed in this study. It analyses her contraction of the disease, stigma, sexuality, support systems and coping mechanisms. The methodology used for the study was framing analysis, which aimed at answering the research questions about the salient themes in the film 'Life Support', socially constructed through Ana's character and through the character of her family and friends. The study shows that one of the most important things to happen to an HIV patient is 'knowledge'. It is an important tool for living and coping with HIV. The study additionally explores the image of HIV/AIDS among African American women. The themes used in the study include life support conversations, Ana's lifestyle as a change agent, and positive and negative relationships.

Chalk's (2014) key finding in her article 'HIV and stigma: the media challenge', was that it was obvious that there has been an excellent response to fighting HIV globally. Stigma however, seems to be one of the greatest challenges an HIV patient has to face daily. She noted that the media is important in this fight against HIV/AIDS, but it is difficult to measure the impact of the media in this fight for societal change. The methodology employed by the author was interview. The interviewees responded that in many countries, training journalists cover real stories about people living with HIV. There are numerous methods of using the media to fight HIV: (i) independent television and radio talk shows (ii) sponsored television and radio talk shows (iii) creation of journalist networks (iv) public service announcements (v) feeding stories into existing dramas (vi) multi-platform approaches (vii) reactive campaigns and (viii) comedy. It was concluded that dramas like 'Soul City' and 'Shuga' are key in making attempts to engage audiences with a storyline, which produces more emotional reaction than factual contents.

Bailey's (2016) thesis titled 'The Representations of HIV/AIDS in Québec Cinema, 1986-1996' was the first comprehensive thesis about how Quebec used film to combat the AIDS predicament. Quebec is unique in the sense that it has an historic cinematic heritage'. The findings of this study maintain that as a result of the distinctive film tradition, Quebec's representation of HIV/AIDS in films were varied and revealing. It questioned the comprehension of HIV/AID in Quebec and Canada in general. It maintained that (i) feature films can bring the subject of HIV to specific and wide audiences (ii) testimonial films can impact the knowledge of HIV (iii) stigma can cause people to question the moral standings of people living with HIV and how creative media can change that perspective and (iv) documentaries can be used as a form of investigative tools to battle stigmatization of HIV victims. 
Online Journal of Communication and Media Technologies, 2019

\begin{tabular}{|c|c|c|c|c|}
\hline & Study & Year & Authors & Key Findings \\
\hline 1. & $\begin{array}{l}\text { Film Portrayal of People } \\
\text { with HIV/AIDS }\end{array}$ & 1998 & $\begin{array}{l}\text { Aitken, Joan; } \\
\text { Dey, Ann }\end{array}$ & $\begin{array}{l}\text { - The movies produced by the mass media focuses narrowly on the portrayal of } \\
\text { sexuality. They focus on the negative sides- they tend to have similar features } \\
\text { e.g. dying. } \\
\text { - They also focus positively on the portrayal of family and community. } \\
\text { - The films are paradoxical in nature, just as the entire AIDS epidemic has } \\
\text { been. }\end{array}$ \\
\hline 2. & $\begin{array}{l}\text { Not Dying from Disease: A } \\
\text { Narrative Analysis of } \\
\text { HIV/AIDS } \\
\text { in the Film Rent }\end{array}$ & 2009 & $\begin{array}{l}\text { Archiopoli, } \\
\text { Ashley M }\end{array}$ & $\begin{array}{l}\text { - The study of each character of the movie led to the creation of the HIV/AIDS } \\
\text { Lifestyle Integration Continuum. Individual lifestyles of the different } \\
\text { characters who are at different stages of HIV are shown. } \\
\text { - The theme of HIV is prevalent throughout the film. }\end{array}$ \\
\hline 3. & $\begin{array}{l}\text { Film: A Supplementary Aid } \\
\text { in Teaching Adults About } \\
\text { HIV/AIDS in Igueben, } \\
\text { Nigeria. }\end{array}$ & 2012 & $\begin{array}{l}\text { Osaigbovo, } \\
\text { Ovbiebo } \\
\text { Matthew } \\
\text { Wood, Lesley }\end{array}$ & $\begin{array}{l}\text { - He stated that film as a campaign strategy impacts in a way that no other } \\
\text { teaching aid can. } \\
\text { - Film is an accessible source of information about HIV to people in that } \\
\text { Igueben community. The results revealed that, films, especially Nollywood } \\
\text { films, play a key role in informing people about HIV/AIDS and its treatment. }\end{array}$ \\
\hline 4. & $\begin{array}{l}\text { Process Evaluation of the } \\
\text { Multiple Concurrent } \\
\text { Partnerships 'O Icheke, Break } \\
\text { the Chain' Campaign for HIV } \\
\text { Prevention in Botswana from } \\
\text { 2009-2012 }\end{array}$ & 2013 & $\begin{array}{l}\text { Mafoko, } \\
\text { Emmanuel }\end{array}$ & $\begin{array}{l}\text { - The results indicate that everything went according to plan, except the } \\
\text { recruitment of campaign champions because of lack of adequate funds. Also, } \\
\text { the support for the district level implementation of campaign activities such } \\
\text { as capacity building and advocacy were also affected by delayed funding. }\end{array}$ \\
\hline 5. & $\begin{array}{l}\text { Perceptions About The O } \\
\text { Icheke Multiple Concurrent } \\
\text { Partnerships Campaign } \\
\text { Among Young People Who } \\
\text { Are Member Of The Selebi } \\
\text { Phikwe District Youth } \\
\text { Council In Botswana }\end{array}$ & 2014 & $\begin{array}{l}\text { Matlapeng, } \\
\text { Kgosiekae } \\
\text { Maxwell }\end{array}$ & $\begin{array}{l}\text { - There are factors fundamental to the practise of sexual multiple concurrent } \\
\text { partnerships in Botswana which include 'financial issues, need for sexual } \\
\text { variety, materialism, unemployment, migration and alcohol abuse. } \\
\text { - The campaign 'O Icheke' also looked into the aspect of provision information } \\
\text { and the impact of partnerships in behavioural change. }\end{array}$ \\
\hline 6. & $\begin{array}{l}\text { HIV Prevention Using Films: } \\
\text { HIV/AIDS Positive African } \\
\text { American Women Respond } \\
\text { through Interpersonal } \\
\text { Relationships in Life Support }\end{array}$ & 2014 & $\begin{array}{l}\text { Moore, } \\
\text { Dakysha; } \\
\text { Onsomu, } \\
\text { Elijah O; } \\
\text { Abuya, Benta } \\
\text { A }\end{array}$ & $\begin{array}{l}\text { - The film 'Life Support' is a source of open dialogue for African American } \\
\text { - Aomen. } \\
\text { - Ann, the protagonist of the story, can be seen as the change agent. } \\
\text { - American are often associated with Fear and shame, among African } \\
\text { - 'Denial' was a prevalent subtheme throughout the duration of the film. } \\
\text { - Positive and negative relationships generally have a positive and negative } \\
\text { impact, as support systems, on the victims of HIV/AIDS. }\end{array}$ \\
\hline 7. & $\begin{array}{l}\text { HIV and Stigma: The Media } \\
\text { Challenge }\end{array}$ & 2014 & Chalk, Sophie & $\begin{array}{l}\text { - Stigma however, seems to be one of the greatest challenges an HIV patient } \\
\text { has to face daily. } \\
\text { - There are numerous methods of using the media to fight HIV: (i) independent } \\
\text { television and radio talk shows (ii) sponsored television and radio talk shows } \\
\text { (iii) creation of journalist networks (iv) public service announcements (v) } \\
\text { feeding stories into existing dramas (vi) multi-platform approaches (vii) } \\
\text { reactive campaigns and (viii) comedy. It was concluded that dramas like 'Soul } \\
\text { City' and 'Shuga' are key in making attempts to engage audiences with a } \\
\text { storyline, which produces more emotional reaction than factual contents. }\end{array}$ \\
\hline 8. & $\begin{array}{l}\text { The Representations of } \\
\text { HIV/AIDS in Québec Cinema, } \\
\text { 1986-1996 }\end{array}$ & 2016 & $\begin{array}{l}\text { Bailey, } \\
\text { Andrew } \\
\text { Gordon }\end{array}$ & $\begin{array}{l}\text { - Feature films can bring the subject of HIV to specific and wide audiences. } \\
\text { - Testimonial films can impact the knowledge of HIV. } \\
\text { - Stigma can cause people to question the moral standings of people living with } \\
\text { HIV and how creative media can change that perspective. } \\
\text { - Documentaries can be used as a form of investigative tools to battle } \\
\text { stigmatization of HIV victims. }\end{array}$ \\
\hline
\end{tabular}

\section{METHOD}

This study adopted content analysis, which is a qualitative method of research. According to Prasad (2008, p. 1) "content analysis is described as the scientific study of content of communication. It is the study of the content with reference to the meanings, contexts and intentions contained in the messages...Thus, content analysis is all about making valid, replicable and objective inferences about the message on the basis of explicit rules. The unit of analysis might be an entire film" (p. 13). This study included a brief synopsis of the television drama series 'Morwalela', to create an understanding and an explanation for the selection of the drama series.

Purposive sampling method (which is a non-probability sampling technique) was used for the selection of the drama series for this study. The type of purposive sampling used 
C. Oduaran, \& O. Nelson

Table 2. Units of analysis for the television drama series 'Morwalela'

\begin{tabular}{|c|c|c|c|c|}
\hline \multicolumn{2}{|r|}{ Themes } & \multirow[b]{2}{*}{$\begin{array}{l}\text { Frequency of } \\
\text { Viewership }\end{array}$} & \multirow[b]{2}{*}{ Direction of Media Frames } & \\
\hline $\begin{array}{l}\text { Positive } \\
\text { Themes }\end{array}$ & Negative Themes & & & \\
\hline Love & Infidelity & Episode & Prevention Tactics & \\
\hline Loyalty & Promiscuity & Number of Views & Testing Procedures & \\
\hline Redemption & Deceit & Number of Comments & Coping Mechanisms & \\
\hline Education & Greed/Materialism & Number of Likes & Transmission Methods & Recurring \\
\hline Hope & Prostitution & & Treatment Procedure & Comments \\
\hline Family & & & HIV/AIDS Discussions & \\
\hline $\begin{array}{l}\text { Truth } \\
\text { Friendship } \\
\text { Community } \\
\text { Tolerance }\end{array}$ & Alcohol Misuse & Number of Dislikes & Stigmatization & \\
\hline
\end{tabular}

was the homogenous purposive sampling technique because the selection of the television drama series by the researchers was based on having the feature of having issues surrounding the HIV/AIDS epidemic in Botswana because it is of interest to the researcher. A homogeneous sample is often chosen when the research question that is being address is specific to the characteristics of the particular group of interest, which is subsequently examined in detail. The reason for the purposively selection by the researcher was to bring focus to a specific feature in the drama series, that will best allow the researcher to find answers to the research questions that have been posed. This should not be regarded as a weakness of the study.

This study was conducted by examining various themes (both positive and negative), the direction of media frames, as well as other factors such as the recurring comments, and the frequency of viewership. The unit for the measurement of the drama series were mutually exclusive and are shown in Table 2. The units that were used to classify the drama series are:

\section{RESULTS}

This study focused on the television drama series 'Morwalela', as one of the major tools in combating HIV/AIDS. The television drama series majorly aimed at promoting positive lifestyle changes, showing prevention and treatment procedure, as well as showing coping mechanisms and rejecting the negative lifestyles and cultural values that aid in transmitting these diseases. Therefore, this study analysed the media frames (cultural issues, lifestyle, prevention, coping and treatment procedures) that address the issue of HIV/AIDS. The following results given below, answers each of the research questions stated in this study.

\section{RESEARCH QUESTION ANALYSIS}

RQ1: What are the prevalent themes in the edutainment drama series 'Morwalela' on HIV/AIDS?

From Table 3, the positive theme of 'Love' had the highest percentage which was 13\%, from 84 scenes, followed by the positive theme of 'Family' with $10.7 \%$. Tolerance was the lowest with $1.2 \%$. Infidelity was the highest negative theme with $11.9 \%$. Therefore, it can be concluded that there is low tolerance for people living with HIV in Botswana. Love and family are two of the most important values in Botswana. The table also shows that infidelity was prevalent in most of the scenes in the drama series. In essence, infidelity is a perennial issue in Botswana; it is a prevailing factor for the increasing cases of HIV/AIDS in the country. This result supports Matlapeng (2014), which found that the 
Online Journal of Communication and Media Technologies, 2019

\begin{tabular}{|c|c|c|}
\hline & Themes & Percentages \\
\hline \multirow{10}{*}{ Positive } & Love & 13 \\
\hline & Loyalty & 6 \\
\hline & Redemption & 3.6 \\
\hline & Education & 7.1 \\
\hline & Hope & 3.6 \\
\hline & Family & 10.7 \\
\hline & Trust & 7.1 \\
\hline & Friendship & 4.8 \\
\hline & Community & 4.8 \\
\hline & Tolerance & 1.2 \\
\hline \multirow{7}{*}{ Negative } & Infidelity & 11.9 \\
\hline & Promiscuity & 4.8 \\
\hline & Deceit & 8.3 \\
\hline & Greed/Materialism & 2.4 \\
\hline & Prostitution & 3.6 \\
\hline & Alcohol Misuse & 7.1 \\
\hline & Total & $\begin{array}{c}100 \\
\mathrm{n}=84\end{array}$ \\
\hline
\end{tabular}

Table 4. The frequency of viewership of the television drama series 'Morwalela'

\begin{tabular}{lcccc}
\hline Episodes & $\begin{array}{c}\text { Number of } \\
\text { views }\end{array}$ & Number of comments & Number of likes & $\begin{array}{c}\text { Number of } \\
\text { dislikes }\end{array}$ \\
\hline $\mathbf{1}$ & 75,800 & 12 & 119 & 10 \\
$\mathbf{2}$ & 23,751 & 3 & 31 & 4 \\
$\mathbf{3}$ & 26,698 & 2 & 27 & 2 \\
$\mathbf{4}$ & 20,827 & 0 & 25 & 4 \\
$\mathbf{5}$ & 14,977 & 0 & 14 & 4 \\
$\mathbf{6}$ & 17,665 & 5 & 30 & 3 \\
$\mathbf{7}$ & 18,078 & 0 & 28 & 1 \\
$\mathbf{8}$ & 17,728 & 1 & 25 & 0 \\
$\mathbf{9}$ & 27,098 & 8 & 35 & 4 \\
\hline
\end{tabular}

need for sexual variety was a an underlying factor for the increase of HIV/AIDS in Botswana. In sum, Morwalela drama series identified infidelity as a public concern that has negatively increased cases of HIV/AIDs in Botswana. Faithfulness to a single partner can arrest the possibilities or chances of being infected by HIV.

Importantly, a primary theme emphasized in Morwalela drama series was showing love for people living with HIV/AIDS (PLWHA). The antidote for stigmatization is showing love, which is the dominant theme emphasized in the drama series. This results supports Chalk's (2014) key findings, which observed that stigmatization seems to be one of the greatest challenges an HIV patient has to face daily. Chalk (2014) maintained that the media is important in this fight against HIV/AIDS.

RQ2: What is the frequency of the viewership of the television drama series 'Morwalela' on its YouTube channel?

From Table 4, episode 1 an episode 9 on the YouTube channel had the highest number of both views and comments. The number of views on the first episode was the highest.

RQ3:What is the direction of media frames in the television drama series 'Morwalela' on HIV/AIDS?

Table 5 shows that $26.7 \%$ of the frames in the movies, out of 30 frames focused on HIV/AIDS discussions and coping mechanisms of HIV/AIDS victims. This is positive because this was the aim of the drama series. It also focused on testing procedures (16.7\%), so that audiences who are in doubt can come to closure. However, treatment 
C. Oduaran, \& O. Nelson

Table 5. Direction of media frames in the television drama series 'Morwalela'

\begin{tabular}{lc}
\hline Direction of media frames & Percentages \\
\hline Prevention tactics & 13.3 \\
Testing procedures & 16.7 \\
Coping mechanisms & 26.7 \\
Transmission methods & 10 \\
Treatment procedure & 3.3 \\
General HIV/AIDS Discussions & 26.7 \\
Stigmatization & 3.3 \\
Total & $\mathbf{1 0 0}$ \\
\end{tabular}

procedures and stigmatization has the lowest number of frames (3.3\%). Thus, a number of media frames focused on coping mechanism for HIV/AIDS in Botswana. This is in line with the current reality that more than $12 \%$ of the population of Botswana were infected with HIV/AIDS. These coping mechanisms were targeted at encouraging citizens of Botswana to live healthy and a long life.

Also, Table 5 shows that general HIV/AIDS discussions were emphasized to encourage Botswana citizens to seek counselling on HIV matters with health care workers and clinical psychologists. Coping with HIV requires that individuals seek out information on health care practices that emphasize intelligent dieting and healthy living standards. This results supports the tenets of the development media theory that stipulates that the media should be the vanguard for health development by creating platforms whereby health professionals can counsel patients on health issues in any modern society.

\section{CONCLUSION}

It can be generalised from this study that the lifestyle shown in the drama series 'Morwalela', is the typical lifestyle in Botswana, which promoted the transmission of HIV/AIDS. The people of Botswana have 'Love' and 'Family' as the most prevalent positive themes, while 'Infidelity', 'Deceit' and 'Alcohol Misuse' are the most prevalent negative themes in Botswana. Over 75, 000 people worldwide have viewed the 'Morwalela' YouTube channel till the time of this study, which shows that the impact of the television drama series is not only in Botswana, but will also be worldwide. Also, it will not be limited to a specific timeframe. It will be accessible as long as it is on YouTube.

Commenters on the YouTube channel shows that the drama series was both educative and entertaining. It also showed that a commenter opined that the drama series revealed the typical Botswana lifestyle. The results also show that the drama series focused more on testing procedures and coping mechanism, keeping the Botswana audiences in mind. However, little focus was given to stigmatization and treatment procedures.

\section{RECOMMENDATIONS}

1. More edutainment drama series like 'Morwalela' should be aired. Both television and radio shows should be aired about behavioural change as key to reducing the epidemic of HIV/AIDS.

2. Potential drama series about HIV/AIDS should focus more on the negatives of stigmatization, alcohol abuse, materialism and promiscuity.

3. Potential drama series about HIV/AIDS should focus more on treatment proceduresthe distribution of Antiretroval drugs and a research on a possible total cure for HIV/AIDS. 
Online Journal of Communication and Media Technologies, 2019

4. The government of other countries-like Lesotho, Swaziland and Nigeria should focus more on partnerships with both governmental and non-governmental organisations. Film should be one of their major tools for fighting the epidemic, as it has been proven in the empirical review of this study that film can get to the places and minds where other informational materials cannot access e.g. rural areas. Research has proven that film has proven to be vital in the fight against HIV/AIDS.

\section{REFERENCES}

Aitken, J., \& Dey, A. (1998). Film Portrayal of People with HIV/AIDS. Kansas City: University of Missouri. https://doi.org/ED419696

Akter, T., \& Dalkılıç, I. (2018). Aesthetic pattern forming of ideological messages in turkish cinema : critical analysis of the Ottoman Republic movie. Online Journal of Communication and Media Technologies, 8(3), 165-180. https://doi.org/10.12973/ojemt/2620

Alawode, S. O. (2013). Home Video as a Nigerian image Maker. European Scientific Journal, 9(11), 110-128.

Archiopoli, A. M. (2009). Not Dying from Disease : A Narrative Analysis of HIV / AIDS in the Film Rent. In Proceedings of the 5th Annual GRASP Symposium, Wichita State University (pp. 74-75).

Avert. (2017). HIV and AIDS in Botswana. Retrieved on April 13, 2018 from http://www.avert.org/node/397/pdf

Bailey, A. G. (2016). The Representations of HIV_AIDS in Québec Cinema, 1986-1996 White Rose eTheses Online.

Booker, N. A., Miller, A. N., \& Ngure, P. (2016). Heavy Sexual Content versus Safer Sex Content: A Content Analysis of the Entertainment Education Drama Shuga. Health Communication, 31(12), 1437-1446. https://doi.org/10.1080/10410236.2015.1077691

Botswana Population (2018) - Worldometers. (2018). Retrieved from http://www.worldometers.info/world-population/botswana-population/

Chalk, S. (2014). Hiv and Stigma: the Media Challenge. International Broadcasting Trust. Retrieved from http://ibt.org.uk/documents/reports/IPPF_IBT_HIV_STIGMA_ final.pdf

Chong, D., \& Druckman, J. N. (2007). Framing Theory. Annual Review of Political Science, 10(1), 103-126. https://doi.org/10.1146/annurev.polisci.10.072805.103054

Costa, N., Faccio, E., Belloni, E., \& Iudici, A. (2014). Drama experience in educational interventions. Procedia - Social and Behavioral Sciences, 116, 4977-4982. https://doi.org/10.1016/j.sbspro.2014.01.1058

Dzimiri, N. (2010). Morwalela TV series launched_ Sunday Standard. Retrieved on April 12, 2018 from http://www.sundaystandard.info/morwalela-tv-series-launched

Evaristus, A., Nelson, O., Olusola, O., Babatunde, A., \& Kehinde, O. (2017). Media Reportage and Audience Perception of Hepatitis Disease in Nigeria, 9(10), 68-77. https://doi.org/10.5539/gjhs.v9n10p68

Framing Theory. (2014). Retrieved from https://masscommtheory.com/theoryoverviews/framing-theory/

Gerbner, G. (1969). Toward "cultural indicators": The analysis of mass mediated public message systems. AV communication review, 17(2), 137-148.

Gwakuba, T. (2010). Morwalela is back _ TheVoiceBW. Retrieved on April 12, 2018 from https://hevoicebw.com/morwalela-is-back/ 
John Hopkins Center for CommunicationPrograms. (2010). INTERSEXIONS. Retrieved on April 25, 2018 from https://ccp.jhu.edu/2010/12/07/intersexions-ccps-tv-seriesabout-sexual-networks-is-top-watched-drama-in-south-africa/

Mafoko, E. (2013). Process evaluation of the multiple concurrent partnerships "o icheke, break the chain" campaign for hiv prevention in botswana from 2009 - 2012 Emmanuel. University of the Western Cape.

Matlapeng, K. M. (2014). Perceptions about the o icheke multiple concurrent partnerships campaign among young people who are members of the selebi phikwe district youth council, Botswana By. University of South Africa.

Moore, D., Onsomu, E. O., \& Abuya, B. A. (2014). HIV Prevention Using Films : HIV / AIDS Positive African American Women Respond through Interpersonal Relationships in Life Support. Open Journal of Social Sciences, 2(November), 110118. https://doi.org/10.4236/jss.2014.211016

Nelson, O., \& Bigala, P. (2016). Creating HIV/AIDS Awareness through Localized Communication for Health Development in South Africa. Journal of Health Management, 18(3), 439-446. https://doi.org/10.1177/0972063416651567

Nemec, J., \& Trna, J. (2007). Edutainment or Entertainment. Education Possibilities of Didactic Games in Science Education. ICCP Word Play Conference, 55-64.

Osaigbovo, O. M. (2012). Film : A Supplementary Aid in Teaching Adults About Hiv / Aids in Igueben (Nigeria).

Oyero, O., Amodu, L., \& Usaini, S. (2015). Film and Production Techniques.

Pasawano, T. (2015). Results of enhanced learning with the edutainment format. Procedia - Social and Behavioral Sciences, 176, 946-951. https://doi.org/10.1016/j.sbspro.2015.01.563

Prasad, B. D. (2008). Content Analysis A method in Social Science Research. Research Methods for Social Work. Retrieved from http://repository.upenn.edu/cgi/viewcontent. cgi?article=1232\&context=asc_papers\&sei-redir=1\&referer=http://scholar.google. com.my/scholar_url?hl=en\&q=http://repository.upenn.edu/cgi/viewcontent.cgi? article=1232\&context=asc_papers\&sa=X\&scisig=AAGBfm23DWDQYw

Setswana Oxford Living Dictionaries. (2018). Setswana Dictionary \& Translations _ Oxford Dictionaries. Retrieved on April 25, 2018 from https://tn.oxforddictionaries.com/

$\mathrm{Su}$, C., \& Salleh, I. (2014). Impact of Television Drama from Audience Reception Perspective. Procedia - Social and Behavioral Sciences, 155(October), 203-208. https://doi.org/10.1016/j.sbspro.2014.10.280

The HIV/AIDS Network. (2011). Wetin Dey_ Good Girls_Bad Girls in TV Drama in Nigeria - The HIV_AIDS Network. Retrieved on April 25, 2018 from http://www.comminit.com/hiv-aids/content/wetin-dey-good-girlsbad-girls-tv-dramanigeria

Tören, Ö. \& Özad, B. E. (2017). Examination of comedy through a television serial: case of Çocuklar Duymasın. Online Journal of Communication and Media Technologies, $7(4), 79-95$.

Tuğçe, E. E. (2018). Storytelling in Crisis Communication. Online Journal of Communication and Media Technologies, 8(2), 131-144. 
Walldén, S., \& Soronen, A. (2004). Edutainment: From television and computers to digital television. University of Tampere Hypermedia Laboratory, (May). Retrieved from http://scholar.google.com/scholar?hl=en\&btnG=Search\&q=intitle:Edutainment+Fro $\mathrm{m}+$ Television+and+Computers+to+Digital+Television\#0

Witteveen, L., \& Lie, R. (2009). International Journal of Educational Development Embedded filming for social change Learning about HIV / AIDS and rural development professionalism, 29, 80-90. https://doi.org/10.1016/j.ijedudev.2008.07. 004

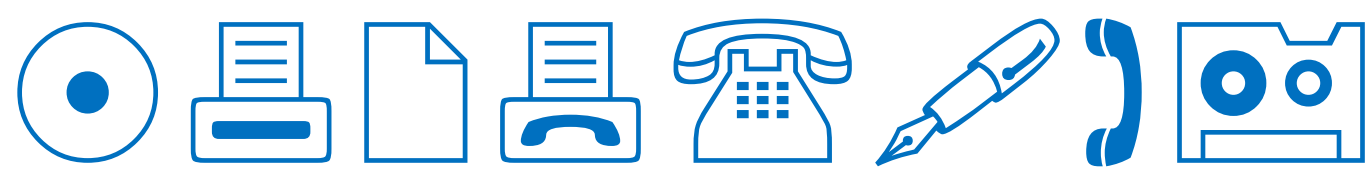

